\title{
ORGANIZATION AND FINANCING OF BIOCHEMICAL RESEARCH IN BRITAIN
}

\section{A} JOINT session of the Biochemical Society and Section I (Physiology and Biochemistry) of the British Association was held in the Department of Biochemistry, University College, Newport Road, Cardiff, during the afternoon of September 7, the closing day of the annual meeting of the British Association. The session was organized on behalf of the Biochernical Society by K. S. Dodgson and W. J. Whelan and took the form of a colloquium, with contributions by nine principal speakers, on "The Organization and Financing of Research in Biochemistry and Allied Sciences in ("reat Britain". The meeting was under the chairmanship of Prof. John Pryde and was attended by about a hundred members of the two organizations.

Prof. A. Haddow, dircetor of the Chester Beatty Research Institute, introduced the subject in a general way, pointing out the unfavourable and widening gap between the research efforts of Britain and those of the United States and the Soviet Union, and then turned more specifically to the organization and financing of the British Empire Cancer Campaign. Dr. F. J. C. Herrald, Sir William slater and Mr. C. Jolliffe described the activities of the Medical Research Council, Agricultural Research Council and Department of Scientific and Industrial Research respectively, while Dr. G. F. Marrian gave an interesting account of the work of the Imperial Cancer Rosearch Fund and of the new research laboratories now under construction in Lincoln's Inn Fields. Prof. F. C. Happold had collated information from professors of biochemistry in Britain, and spoke of the problems, particularly financial, which are facing university biochemists. 'l'he activities of industry (particularly the pharmacentical industry) in the field of biochemistry were outlined by Dr. F. A. Robinson, of Allen and Hanburys, Ltd., while Dr. J. B. Bateman, deputy scientific attache to the American Embassy, spoke of the contributions of the United States in providing support for biochemistry and related sciences in Britain. Finally, Prof. A. Neuberger summarized the proceedings and pointed to the steps which need to be taken if Britain is to maintain its high position in the field of biochemical research.

Contacts with numerous members of the audience prior to the meeting suggested that the real problems surrounding biochemical research are financial rather than organizational. In this connexion, a glance at the list of participants might have indicated that the speakcrs could be separated into two categories, namely, those distributing financial aid and those receiving it. The possibility of the meeting dividing sharply into two factions thus existed but, happily, did not materialize. Indeed, thero was a general appreciation of the considerable assistance which various bodies have provided for all fields of biological rescarch with the funds at their disposal, and of the sympathetic way in which applications are handled by them. In turn, it was clear that officials of these bodies are well aware of the problems facing research biochemists, particularly those working within the universities.
Several points of importance emerged during the course of the meeting. In the first place, it was clear from figures presentied by Prof. Haddow that, in spite of the difficulty of translating the currency figures of various countries into absolute and meaningful terms, there is a widening gap between the amount of financial aid available for research in biological and medical sciences in Britain compared with that available in the United States or the U.S.S.R. Prof. Haddow reminded his audience of the blunt words of Sir Harry Melville earlier this year: "Whother we like it or not, the age of string and sealing wax has come to an end, and the pursuit of scientific knowledge is now a rather expensive and complex affair in which substantial resources in men, material and facilities are necded". Apart from the discrepancy in financial effort, there is also some degree of contrast between the principles applied in financing research in the United States and those applied in Britain. In the United States, money is being provided for medical research, including biochemistry, on a scale which we in Britain would regard as lavish. There is a tendency to assume that expansion on this seale must inevitably result in a dilution of scientific standards and attainments. In fact, there is increasing evidence to show that the great and rapid expansion resulting from the Amorican system has not diluted scientific standards, but rather has elicited talent which might otherwise not have becorne manifest.

In contrast, financial assistance for research in Britain is not so readily available, and the case must be forcefully and compellingly presented to the appropriate organization in order to obtain the nocesssary financial support. In considering applications for financial assistance, the Medical Research Council, the Agricultural Research Council and the Department of Scientific and Industrial Research attach great (perhaps too much) significance to the ability and reputation of the grant-seeker and the 'timeliness and promise' of the proposed research work. However, what might appear to be of timeliness and promise at the moment may not appear so twelve months hence. Other work which appears to have little import or significance at the time (and which may therefore remain unsupported) may well provide the vital answer to a problem which develops in five or ten years time. In order to cope with this problem, so far as university dopartments of biochemistry and allied sciences are concerned, Prof. Trappold pleaded that the universities themselves should be given more adequate sums for distribution among their departments. The distribution of such sums should bo under the control of an internal university committee composed of those in a position to judge the needs. Prof. Happold pointed out that it is the universities (the source of a large proportion of the rescarch in biochemistry and other biological sciences) which are particularly affected by inadequate financial support. Indeed, the head of a department had informed him that, "If the apparatus which has been bought with gifts from the Royal Society, the Rockefeller Foundation or the M.R.C. were taken 
away from this department, I can safely say that every single major line of research at present being pursued here would stop at once". Support for Prof. Happold's plea came from the body of the meeting during discussion periods, and it was clear that a strong feeling existed that university departments urgently need greater financial support from within the universities themselves.

Two further inter-related points which emerged from the colloquium were, first, that biochemistry is still primarily a research subject, and secondly, that there is already a shortage of trained biochemists in Britain. In relation to the first point, Dr. Robinson produced some interesting figures which suggested that comparatively few biochemists are employed in industry and that, generally speaking, they tend to take subordinate roles. However, Dr. Robinson did stress that his figures related particularly to the pharmaceutical industry, and it seems to the present writers that reference to other industries, for example, the food industry, might provide a more favourable picture. On the second point, Sir William Slater pointed out that it has become increasingly difficult to obtain suitably qualified research biochemists and that the brakes on the progress of the biochemical work of the Agricultural Research Council have not been shortage of funds but shortage of the right men. Further point was given to this statement by Dr. Marrian, who said that the development of the work of the Imperial Cancer Research Fund and the opening of its new Institute will mean that the number of qualified research workers employed by the Fund will increase from the present level of about 30 to between 80 and 100 by $1964-65$. Approximately one-third of these will probably be biochemists. At the present rate at which trained biochemists are emerging from the universities, one suspects that Dr. Marrian will experience difficulty in recruitment on this scale.

In his summarizing remarks, Prof. Neuberger struck at the very root of this problem by pointing out that several British universities do not yet have departments of biochemistry, and he appealed to the Iniversities to see that this defect is speedily remedied. In his own University of London, although there are a number of biochemistry departments concerned with the instruction of medical students, there are only two departments catering for a science degree in the subject, and the combined intake of these departments is limited to about twenty students a year. Prof. Neuberger further stressed the frustration felt by university biochemists of high standing who are unable to progress to senior status because of the rigidity of establishment. He pleaded for the speedy creation of new chairs of biochemistry and the introduction of personal chairs in this and related subjects. Citing the case of Harvard University, with its five professors within what is probably the best organic chemistry department in the world, Prof. Neuberger said that this is one aspect of the American university system that we should be prepared to adopt.

Bearing in mind the comments of Dr. Robinson regarding the subordinate position of biochemists in industry, Prof. Neuberger suggested that it might be time to do some re-thinking as to the way in which biochemists in Britain are trained. For example, is a training in organic chemistry being given which is sufficient for the needs of industry? Should the universities encourage the biochemist who is perhaps not ideally suited for a research position to think of a teaching post in a grammar or public school ? The student population of the schools might then become more aware of the possibilities of biochemistry as a career, and this in turn might stimulate the flow of recruits to the profession.

During the two periods which were allocated to discussion, many members of the audience took the opportunity to ask questions and to state their own views. From later discussions which took place during an informal supper, it was clear that the colloquium had been a most successful venture and, in particular, many people expressed their appreciation of the co-operation of the various research councils and similar organizations in providing such interesting accounts of their activities. The meeting has raised a number of points which appear to merit further investigation and a number of problems which, it seems to the present writers, should now be actively pursued by the Biochemical Society for the good of British biochemistry and, indeed, for science as a whole.

K. S. DODGSON

J. Pryde

\section{RESEARCH FOR INDUSTRY}

" $\mathrm{R}$ ESEARCH for Industry 1959"* follows the general pattern of the previous year's report. The report of the Industrial Grants Committee, which this year discusses the coverage of the Government scheme and co-operation in three specific areascreep research, fatigue of metals and shipbuilding research-is accompanied by a review of the achievements of a dozen of the Associations, the terms of grant of which have been reviewed during the year; and, under "The Research Associations To-day", there is the now customary list of Associations, giving their officers, income, publications and a brief indication of the present scope of the work of each Association. To the total income of the Associations

* Department of Scientific and Industrial Research. Research for Industry 1959: a Report on work done by Industrial Research Associations in the Government Scheme. Pp. iv $+126+12$ plates.
(London: H.M. Stationery Office, 1960.) 8s. net. in 1959 of $£ 7.3$ million, the Department of Scientific and Industrial Research contributed $£ 1 \cdot 7$ million.

In place of the two special chapters in last year's report dealing with the place of the research associations in the evolution of scientific endeavour and the service of co-operative research to the textile industry, there is a chapter by Dr. $J$. Thomson on instrumentation and automatic control in industry, which surveys briefly recent progress in this field in various industries, particularly under the headings of detecting elements, indicators and recorders, and controllers. The British Scientific Instrument Research Association seeks first to serve the scientific instrument industry and secondly, to bring large users of instruments into contact with manufacturers. Besides current investigations into the structure and control of thin films, of glassy phosphors, particularly 